\title{
Drug Accountability Date Time
}

National Cancer Institute

\section{Source}

National Cancer Institute. Drug Accountability Date Time. NCI Thesaurus. Code C88014.

The date and time of the drug accountability data. 